\title{
STUDYING THE RELATIONSHIP BETWEEN TEXT COMPREHENSION ABILITY AND GRADE TEN STUDENTS' VOVABULARY ACQUISITION IN NARRATIVE TEXT
}

\author{
Agus Gunawan ${ }^{1}$, Annisa Septiani
}

Universitas Islam As-Syafi'iyah Jakarta

\begin{abstract}
This research entitled "Studying the Relationship between Text Comprehension Ability and Grade Ten Students' Vocabulary Acquisition in Narrative Text at SMK BHAKTI PERASADA, Bekasi" principally aims to investigate whether or not relationship between Text Comprehension Ability and grade ten Students' Vocabulary acquisition in Narrative Text. The research samples were taken using cluster random sampling, with the total number of samples being 36 students. The location of this research was SMK BHAKTI PERSADA, Bekasi, conducted from $15^{\text {th }}$ to $22^{\text {nd }}$ November 2016. The research methodology adopted was the quantitative, correlational research. With the research design being ex post facto(after the fact).To collect data, the students were given objective test, numbering 68 items. The research data were analyzed descriptively and inferentially. The findings indicated that there was significant relationship between text comprehension ability and grade ten students' vocabulary acquisition in narrative text at SMK BHAKTI PERSADA, Bekasi. It can be seen from the data analysis using Pearson's Product Momentthat showed $t_{\text {observed }}$ (4.93), which was higher than the critical value of $t_{\text {table }}$ (at the significant level of 0.05 and $\mathrm{df}=1 / 35$ ), namely 2.03 . It means that text comprehension ability has significant correlation with vocabulary acquisition in narrative text.
\end{abstract}

The key words: Text Comprehension Ability, Vocabulary Acquisition. 


\section{Introduction}

English became the most important foreign language in Indonesia, it is caused English is the most dominant international language that most people around the world use for communicate each other.

Vocabulary acquisition is very important in learning English as the key for students to communicate successfully with other people and also to understand what they hear and read text in school. Vocabulary plays an important role. It is one element that links the four skills of speaking, listening, reading, and writing. For these reasons, it is very important for students to quickly build up a large store of vocabulary. On KTSP 2006 in Senjaya (2013) explain that:

Memang diakui bahwa seseorang tidak mungkin akan dapat berkomunikasi dengan baik kalau pengetahuan kosakatanya rendah dan agar dapat menguasai keterampilan (listening, reading, speaking, dan writing) tersebut diatas dengan baik, siswa perlu dibekali dengan unsurunsur bahasa, misalnya kosakata (vocabulary).

Ideally, standard competency of KTSP for grade ten students in Senior High School that the students are able to communicate in English by mastery 2.500 vocabularies. Unfortunately, the condition that mentioned above has not been satisfactorily achieved. As evidenced from the fact that students' performance or achievement in English is still low. It is because less motivation in learning vocabulary. The real condition Nurhemida, on the research found (2007) that: "The findings revealed that the Indonesian senior high school students had only 1.000 to 2.000 vocabularies. This is one of the reason why students often 
grumbled and confused when they read the text. They difficult to understand about the text because they don't have vocabulary acquisition.

Additionally, teachers also sometimes do not have good technique in English teaching that can help students in comprehending English text. Consequently, Teachers should know about students need in learning English and give the proper way to teach them. Because students need the way how to enrich their vocabulary, so students have the ability in text comprehension, especially in narrative text.

Based on the problems above, this research was conducted to investigate whether or not relationship between Text comprehension ability and Grade Ten Students' Vocabulary acquisition in Narrative Text. Sedita (2005) who states that "Vocabulary knowledge is crucial in reading comprehension and determining how well students are in comprehending the texts. In the regard to this matter, this study attempts to find out the ability of students' text comprehension, students' vocabulary acquisition and the correlation between students' text comprehension and their vocabulary acquisition'. There are many researchers that proved text comprehension ability has relationship with vocabulary acquisition.

The previous researcher that revealed text comprehension ability correlate with vocabulary acquisition are: 1.) Dr. Selma Kara (2013) that revealed the result of the research is there is a significant relationship between vocabulary learning through word-focused activities and text comprehension. 2.) Ahmed Shakir Al Kialbi (2015) revealed that the result of analysis for the collected data 
indicated a significant correlation between reading comprehension and second language acquisition. 3.) Dr. Saeed Mehrpour (2011)found that the result of the study is there was significant correlation between vocabulary knowledge and reading comprehension. The results obtained from the analysis of the data indicated that vocabulary knowledge play an important role in EFL learners' reading comprehension performance, depth of vocabulary knowledge makes a more important contribution. 4.) Diana Pulido (2007)that revealed the result of the research is there is a significant relationship between text comprehension ability and vocabulary development.

Based on the explanation above, this research aims to find out the relationship between text comprehension ability and grade ten students' vocabulary acquisition in narrative text at SMK BHAKTI PERSADA Bekasi, the research question is formulated as follows: "Is there any relationship between text comprehension ability and grade ten students' vocabulary acquisition in narrative text at SMK BHAKTI PERSADA, Bekasi?"

\section{Method}

\section{Hypotheses}

To find out whether or not there is significant relationship between text comprehension ability and students' vocabulary acquisition, the hypotheses are formulated as follows:

1.Null Hypothesis $\left(\mathrm{H}_{0}\right)$ 
There is no significant relationship between text comprehension ability and grade ten students' vocabulary acquisition in narrative text at SMK BHAKTI PERSADA, Bekasi.

2.Alternative Hypothesis $\left(\mathrm{H}_{\mathrm{a}}\right)$

There is significant relationship between text comprehension ability and grade ten students' vocabulary acquisition in narrative text at SMK BHAKTI PERSADA, Bekasi.

\section{Research Design}

In this research, the researcher used Ex Post Facto (after the fact) method, which examines the relationship between independent and dependent variables. The independent variable in this research is text comprehension ability, and the dependent variable of this research is vocabulary acquisition in narrative text. The students were tested by these two variables into instruments. The total of question is 68 questions from both instruments.

\section{Participants}

The population of this research is grade ten students at SMK BHAKTI PERSADA in academic year 2016/2017 at the first semester, consisting of 129 (a hundred and twenty nine) students. To determine the sample of this research, the writer used Cluster Random Sampling. The number of students that participated in this research is about 36 (thirty six) students in X AK as a sample class.

\section{Variables and Measures}

In this research, independent variable is text comprehension ability and dependent variable is vocabulary acquisition in narrative text. To measure 
students' text comprehension ability and students' vocabulary acquisition, the writer took score from the indicators. The indicators for students' text comprehension ability are as follows:

1.The students are able to answer the questions based on the narrative text.

2.The students are able to distinguish between main idea and supporting details in narrative text.

3.The students are able to summarize the passage in narrative text.

4.The students are able to define word meaning in narrative text.

5.The students are able to show the passage about narrative text.

6.The students are able to classify the statement true or false based on the narrative text.

The indicators for students' vocabulary acquisition are as follows:

1.The students are able to select the synonym of the words.

2.The students are able to select the antonym of the words.

3.The students are able to recognize homophone words.

4.The students are able to identify the base words.

5.The students are able to connect between target words and known words.

6.The students are able to recognize simple, unfamiliar words.

\section{Validity and Reliability}

The indicators of text comprehension ability and vocabulary acquisition in narrative text were developed to be instruments. The instruments were objective test with 120 question items. Those items were analyzed its validity using 
Pearson's Product Moment Correlation Coefficient, and reliability using Alpha Cronbach formula which analyzed on IBM SPSS 20', difficulty index and discrimination power to obtain good instruments using Microsoft Excel 2007. After the items have been analyzed, the good items that valid, reliable, satisfactory and medium were chosen to obtain good data. The question items for text comprehension ability instrument were left 32 numbers, and the question items for vocabulary acquisition in narrative text instrument were left 36 numbers. 


\section{Procedure}

Procedures of the research are:

1. Planning

Planning phase of this research is preparing and arranging the research design to get the research data. Before conducting the research, the writer formulates the hypotheses based on some related theories.

2. Collecting Data

The data were collected by giving test in a sample class to the students.

3. Data Analysis

The data collected from the sample class were analyzed by using IBM SPSS

20' based Pearson' Product Moment after the pre-requisite analyses of normality and linearity have been fulfilled.

4. Reporting

The research finding is reported and written based on the formal frame of writing.

\section{Result}

The research data were analyzed descriptively and inferentially. The descriptive statistic can be seen on the following table. 
Table 1: Descriptive Statistics

\begin{tabular}{|l|c|c|}
\hline \multicolumn{1}{|c|}{ Valid } & $\begin{array}{c}\text { Text_Compreh } \\
\text { ension Ability }\end{array}$ & $\begin{array}{c}\text { Vocabulary_Acquisition } \\
\text { in Narrative Text }\end{array}$ \\
\hline Missing & 36 & 36 \\
Mean & 0 & 0 \\
Std. Error of Mean & 84.61 & 90.42 \\
Median & .900 & .792 \\
Mode & 84.00 & 92.00 \\
Std. Deviation & 81 & 94 \\
Variance & 5.400 & 4.753 \\
Skewness & 29.159 & 22.593 \\
Std. Error of Skewness & .315 & -.523 \\
Kurtosis & .393 & .393 \\
Std. Error of Kurtosis & -1.073 & -.851 \\
Range & .768 & .768 \\
Minimum & 18 & 16 \\
Maximum & 76 & 81 \\
Sum & 94 & 97 \\
\hline
\end{tabular}

a. Multiple modes exist. The smallest value is shown

From the table above it can be described variable X (Text Comprehension Ability) has Range score is 18 , Minimum score is 76 , Maximum score is 94 , total score is 3046 , Mean score is 84.61 , Median score is 84.00 , Mode score is 81 , Std. Deviation score is 5.400, and variance 29.159. Also from the analysis above it can be described variable Y (Vocabulary Acquisition in Narrative Text) has Range score is 16 , Minimum score is 81 , Maximum score is 97 , total score is 3255 , Mean score is 90.42, Median score is 92.00, Mode score is 94, Std Deviation score is 4.753 , and variance 22.593 .

After the data were analyzed descriptively, the data were analyzed inferentially using IBM SPSS 20' based Pearson' Product Moment. The data were 
tested its normality (Kolmogorov Smirnov) and its linearity (Anova ${ }^{a}$ ) as prerequisite data analysis. The result of data analysis is presented as follows:

Table 2: Pearson' Product Moment Correlation

\begin{tabular}{|cc|c|c|}
\hline & & $\begin{array}{c}\text { Text_Comprehen } \\
\text { sion }\end{array}$ & $\begin{array}{c}\text { Vocabulary_Acq } \\
\text { uisition }\end{array}$ \\
\hline \multirow{2}{*}{ Text_Comprehension } & Pearson Correlation & 1 & $.645^{* *}$ \\
& Sig. (2-tailed) & & .000 \\
& $\mathrm{~N}$ & 36 & 36 \\
Vocabulary_Acquisition & Pearson Correlation & $.645^{* *}$ & 1 \\
& Sig. (2-tailed) & .000 & 36 \\
\hline
\end{tabular}

**. Correlation is significant at the 0.01 level (2-tailed).

The calculation showed that significant value is 0.000 . The significant value $0.000<0.05$, so $\mathrm{H}_{\mathrm{o}}$ was rejected and $\mathrm{H}_{\mathrm{a}}$ was accepted. $\mathrm{t}$ observed also can be used to find out whether or not there is significant correlation between two variables of variable $\mathrm{X}$ on $\mathrm{Y}$ through comparing with $\mathrm{t}$ table. Degree of freedom was used to find out $t$ table, (df) $(1,35)=2.03$. The result showed that $t$ observed (4.93) $>\mathrm{t}$ table (2.03). It can be concluded that there is significant correlation between variable $\mathrm{X}$ (Text Comprehension Ability) and variable Y (Vocabulary Acquisition in Narrative Text).

\section{Discussion}

This research was based on the theories advanced by Dr. Selma Kara (2013), Diana Pulido (2007), Dr. Saeed Mehrpour (2011), and Ahmed Shakir AlK ialbi (2015) who pointed out that Text Comprehension Ability correlated with Vocabulary Acquisition in learning vocabulary for second language learners. The result of the current study were consistent with a number of studies done by the researchers above, indicating that Text Comprehension Ability correlated with 
Vocabulary Acquisition in Narrative Text have significant positive correlation. All researchers were doing test based on Nation Vocabulary Level Test (VLT) which had 2000, 3000, and 5000 levels and the students are better in doing the vocabulary test at the 2000 and 3000 levels than at the 5000 level of VLT. This indicates a better result compared with their previous study who found that students only had 1040 English words.

The research which was conducted by the writer in SMK BHAKTI PERSADA, Bekasi in the academic year of 2016/2017, involving 36 students of the grade ten in the sample class, showed that there is significant correlation between text comprehension ability and ten students' vocabulary acquisition in Narrative Text. The test was made clear by the result of calculation using Pearson's Product Moment statistics IBM SPSS 20whichsignificance value (sig,) 0.000 is lower than (<) 0.05 and sig. (2-tailed) is lower than 0.05 in SPSS 20 (sig. (2-tailed) $(0.000)<0.05)$. The research indicated the rejection of Ho and the acceptance of Ha. Therefore, the research conducted by the writer supported the theories and empirically verified the previous studies by the afore-mentioned researchers Dr. Selma Kara (2013), Diana Pulido (2007), Dr. Saeed Mehrpour (2011), and Ahmed Shakir Al Kialbi (2015).

\section{Conclusion}

The research findings revealed that there is significant relationship between text comprehension ability and grade ten students' vocabulary acquisition at SMK BHAKTI PERSADA, Bekasi. Increasing students' English vocabulary acquisition involves the text comprehension ability, so that in each 
individual has the potential to develop their vocabulary acquisition based on having a text comprehension ability. In practicing their text comprehension, the students should deepen the ability and recognition of vocabulary acquisition. It is suggested that the teachers of English are suggested have to discuss kinds of text especially narrative text when they are teaching vocabulary, also for the students are suggested to learn more vocabulary in narrative text, by obtaining a deep understanding of vocabulary. The writer also suggested for school that encourage the teachers of English to disclose and discuss kind of text when they are teaching vocabulary, and for the future researchers who are interested in this area are suggested that they adopted better research methodology, and this research can be reference in developing the writer's knowledge about teaching and learning. 


\section{REFERENCES}

Al farisi, Badriya. 2008. Morphological Awareness and Its Relationship to Vocabulary Knowledge and Morphological Complexity among Omani EFL University Students. Asutralia: The University of Queensland.

Alexander, Francie. 2014. Understanding Vocabulary. www.sholastic.com/teachers/ article/understanding-vocabulary. Retrieved on $20^{\text {th }}$ February 2016.

Association, American Counseling. 2009. The ACA Encyclopedia of Counseling. USA: Wiley Publishers.

Carrell, Praticia L and Joanne Devine. 1998. Interactive Approaches to Second Language Reading. United Kingdom: Cambridge University Press.

Cooper, Geoffrey. 2003. Intelligent the Student's Guide to Learning at University. Australia: Mercury Printeam

Don, Jan. 2014. Morphological Theory and The Morphology of English. Great Britain: Edinburgh University Press.

Dugan, Christine. 2010. Strategies for Building Academic Vocabulary in Social Studies. Huntington Beach: Shell Education.

Florida, University of Central. 2011. Differentiated Instruction for Vocabulary.www.faculty.scf.edu/sharric/lesson7/lesson7topic7.htm\#. Retrieved on $16^{\text {th }}$ January 2016.

Foucault, Michel. 1972. Archaeology of Knowledge. United Kingdom: Tavistock Publications Limited.

Hall, Parley Cougar. 2008. Potential Predictors of Student Teaching Performance: Considering Emotional Intelligence. Utah: The University of Utah.

Haspelmath, Martin and Andrea Sims. 2010. Understanding Morphology. New York: Routledge.

Khodadoust, Ehsaneh, Seyed Hesamiddin Aliasin, and Robab Khosravi. 2013. The Relationship between Morphological Awareness and Receptive Vocabulary Knowledge of Iranian EFL Learners. India: Society of Education.

Klein, Wolfgang. 1994. Time in Language (Germanic Linguistics). Netherlands: Routledge.

Knoff, Howard M. 2009. Developing and Implementing the Behavioral Matrix. USA: Project Achieve Press.

Krishnamurti, J. 1965. Choiceless Awareness 1. London: The Collected Works.

Latifi, Zahra, Morad Bagherzadeh Kasmani, Seyed Hassan Talebi, and Kamran Esmaeelnia Shirvani. 2012. Morphological Awareness and Its Relationship to Vocabulary Size and Morphological Complexity Among Iranian EFL University Students. Iran: Mazandaran University

Lauber, Stephen. 2014. Vocabulary Development Part 1: Types of Vocabulary.www.dataworks-ed.com/vocabulary-development-part-1-types-ofvocabulary/. Retrieved on $16^{\text {th }}$ January 2016.

Lawrence, Jessika Michelle. 2008. Differences in Morphological Awareness Skills Between Children with Phonological Impairment and Children with Typical Development. United State: UMI Microform.

Ma, Qing. 2009. Second Language Vocabulary Acquisition. Great Britain: International Academic Publishers.

Mackewn, Jennifer. 1997. Developing Gestalt Counseling. London: SAGE Publications Ltd.

Marshall, Chloe R. 2013. Current Issues in Developmental Disorcers. New York: Psychology Press

Matthews, P. H. 1991. Morphology. United Kingdom: Cambridge University Press. 
Melcuk, Igor A. 2012. Semantic: From Meaning to Text, Volume 1. Amsterdam: John Benjamins Publishing.

Nation, Paul. 2014. School of Linguistics and Applied Language Studies. www.victoria.ac.nz/lals/about/staff/paul-nation. Retrieved on 16th January 2016.

Nur and Hadi. 2014. The $1^{\text {st }}$ Academic Symposium on Integrating Knowledge. Malaysia: Universiti Teknologi Malaysia.

Nurhemida. 2007. The Relationship between Morphological Awareness and English Vocabulary Knowledge of Indonesian Senior High School Students. Australia: The University of Queensland.

Roberts, Lauren Cahoon. 2014. 9 Ways Going to College Affects Your Health.www.livescience.com/39366-how-college-affects-health.html. Retrieved on $30^{\text {th }}$ December 2015.

Shafaei, Azadeh and Mehran Nejati. 2009. Annals of Language and Learning: Prceedings of the 2009 International Online Language Conference (IOLC 2009). Florida: Universal Publisher.

Siemens, George. 2006. Knowing Knowledge (Online Version).

Stangor, Charles. 2014. Research Method for the Behavioral Sciences. New York: Wadsworth Publishing.

Strictly. 2013. Toefl Tip \#207: Active vs. Passive Vocabulary.www.strictlyenglishusa.com/blog/2013/06/toefl-tip-207-active-vspassive-vocabulary/. Retrieved on $16^{\text {th }}$ January 2016.

Tabatabaei, Omid and Masumeh Yakhabi. 2011. The Relationship between Morphological Awareness and Vocabulary Size of EFL Learners Vol. 4. Iran: Islamic Azad University.

Tschirner, Erwin. 2004. Breadth of Vocabulary and Advanced English Study: An Empirical Investigation. Germany: University of Leipzig

Weston, J. Walch. 2003. Content-Area Vocabulary Strategies for Social Studies. Portland: Walch Publisher.

Widyaiswara, Fahrawati. 2014.Bahasa Inggris dan Pengaruhnya Terhadap Kurikulum Pendidikan di Indonesia. http://makassar.tribunnews.com/2014/02/19/pengaruhbahasa-inggris-terhadap-kurikulum-pendidikan. Retrieved on $20^{\text {th }}$ November 2015. 